Jurnal

Kardiologi Indonesia

J Kardiol Indones. 2014;35:162-70

ISSN $0126 / 3773$

\title{
Secretory Phospholipase A2 Tipe II (SPLA II) In Cardiovascular Disease
}

Department of Cardiology And Vascular Medicine Faculty Of Medicine, Brawijaya University, Malang

\author{
Dianggan Sargowo
}

Inflammatory reactions contribute to the pathogenesis of cardiovascular conditions such as atherosclerosis and ischemic damage in acute myocardial infarction (AMI). Among the mediators involved in inflammation are secretory phospholipase A2 group II (sPLA2-II) enzymes. Though some cells constitutively express Spla2-II, the synthesis by cells such as hepatocytes is typical for an acute-phase reactant. Recent literature suggest multiple roles for sPLA2-II in cardiovascular disease. In this review we discuss the role of sPLA2-II in included that sPLA2-II appears to be an inportant inflammatory mediator of cardiovascular disease.

(J Kardiol Indones. 20 I4;35:162-70)

Keywords: Phospholipase, Ischemia, Infection, Inflamation, Atherosclerosis. 


\title{
Secretory Phospholipase A2 Tipe II (SPLA II) Pada Penyakit Kardiovaskuler
}

\author{
Djanggan Sargowo
}

\begin{abstract}
Reaksi inflamasi berperan dalam beberapa pathogenesis kondisi kardiovaskuler seperti atherosklerosis dan kerusakan iskemik pada infark miokard akut (IMA). Di antara mediator-mediator yang terlibat dalam inflamasi tersebut adalah enzim secretory phospholipase A2 tipe II (sPLA2-II). Meskipun beberapa sel memang memproduksi sPLA2-II, namun sintesis oleh sel-sel tertentu seperti hepatosit, adalah khas sebagai reaktan fase akut. Literatur terbaru menyatakan banyaknya peran dari sPLA2-II dalam penyakit kardiovaskuler. Dalam tulisan berikut, akan mendiskusikan peran sPLA2-II dalam berbagai model atherosklerosis atau IMA, baik in vitro maupun in vivo, termasuk perspektif terapeutik dari sPLA2-II inhibitor. Disimpulkan bahwa sPLA2-II merupakan mediator inflamasi yang penting dalam penyakit kardiovaskuler.
\end{abstract}

(J Kardiol Indones. 2014;35:162-70)

Kata kunci: phospholipase, iskemia, infeksi/inflamasi, atherosclerosis

\section{Pendahuluan}

Atherosklerosis dan IMA adalah kondisi kardiovaskuler mayor di dunia barat. Dulunya, kondisi tersebut dianggap akibat dari abnormalitas lipid, dan faktor resiko lain seperti hipertensi, merokok, hiperhomosisteinemia, dan diabetes. Meski demikian, bukti-bukti saat ini menambahkan bahwa reaksi inflamasi pada lesi atherosklerotic serta IMA, memiliki efek besar dalam insidensi dan outcome dari atherosklerosis dan IMA. Contohnya, sejumlah studi menunjukkan bahwa level plasma dari C-reactive protein (CRP), sebuah marker inflamasi, merupakan penanda resiko independen untuk kejadian kardiovaskuler baik

\footnotetext{
Alamat Korespondensi

Prof. DR. dr. Djanggan Sargowo, SpPD, SpJP(K). Deaprtemen Kardiologi dan Kedokteran Vaskular FK Universitas Brawijaya/RS Saiful Anwar, Malang. E-mail: djanggan@yahoo.com
}

untuk orang sehat maupun untuk orang dengan penyakit kardiovaskuler seperti stable angina. Efek menguntungkan dari statin pada awalnya adalah karena statin merupakan obat penurun kolesterol. Banyak proses yang terlibat dalam pembentukan atherosclerotic pada pembuluh darah dalam berbagai stage, seperti pola influx dan aktivasi sel mononuclear, yang menunjukkan kesamaan proses dalam penyakit imun/inflamasi. Berkembangnya pengertian tentang inflamasi dalam atherosclerosis telah menimbulkan spekulasi bahwa kondisi ini mungkin dapat meningkat akibat infeksi mikroba seperti Chlamydiae pneumonia atau virus. Studi patologis dari jantung pasien yang meninggal akibat IMA menunjukkan bukti adanya reaksi inflamasi pada miokard yang iskemia dimulai sejak beberapa jam setelah onset. Beberapa studi pada hewan menunjukkan bahwa agen anti-inflamasi dalam beberapa kondisi dapat menurunkan ukuran infark secara substansial pada IMA. Studi klinis awal dengan 
inhibitor complemen $\mathrm{C} 1$ menunjukkan hasil yang menggembirakan ${ }^{1-4}$.

Reaksi inflamasi dimediasi oleh mediator inflamasi diantaranya sitokin, komplemen, dan lainlain. sPLA2-II merupakan salah satu mediator inflamasi yang mungkin terlibat dalam pathogenesis atherosclerosis dan IMA. Peran dari enzim sPLA2-II pada kedua penyakit tersebut, mulai diperhatikan karena ternyata level sPLA2-II dalam darah meningkat saat atherosclerosis dan IMA².

Sebagai tambahan, sPLA2-II juga terdeposit dalam arteri atherosclerotic serta pada cardiomyocyte yang mengalami iskemia. Kami mendiskusikan pokok masalah bahwa sPLA2-II dapat meningkatkan atherosclerosis dan memiliki efek memperburuk iskemia cardiomyocyte pada IMA, dan bahwa enzim sPLA2-II harus dianggap sebagai mediator inflamasi pada penyakit kardiovaskuler, dan bukan hanya fenomena sampingan ${ }^{3}$.

\section{Enzim Phospholipase A2 (PLA2)}

PLA2 merupakan enzim dengan banyak isoform termasuk secretory phospholipase A2 dengan berat 14$\mathrm{kDa}($ PLA2) dan cytosolic phospholipase A2 dengan berat $85-\mathrm{kDa}$ (cPLA2). sPLA2 terdiri dari sejumlah protein homolog dengan 5 hingga 8 jembatan disulfida. Lokasi dari ikatan disulfida tersebut adalah pada bagian belakang protein sehingga menjadi dasar dari klasifikasi enzim menjadi beberapa subgrup $^{2}$.

sPLA2-I dikenal sebagai pancreatic PLA2, karena memang diekspresikan dalam jumlah besar di pancreas, kemudian disekresikan di usus yang kemudian enzim tersebut menghidrolisis phospholipid dari makanan ${ }^{1}$.

Sejumlah besar mRNA dari sPLA2-I juga ditemukan di limpa, paru, dan prostat. sPLA2-II awalnya ditemukan di cairan synovial pasien dengan arthritis rheumatoid (RA), dan kemudian ditemukan sebagai protein fase akut, dimana levelnya disirkulasi dapat meningkat 100 kali lipat selama reaksi fase akut. sPLA2-I dan sPLA2-II merupakan protein ekstrasel yang disekresi oleh sel, sedangkan cPLA2 merupakan protein sitoplasmik intrasel, dimana mRNA pengkodenya ditemukan dibanyak jaringan seperti jantung, limpa, paru, dan ginjal ${ }^{3}$.

Enzim PLA2 menghidrolisis phospholipid pada posisi sn-2 sehingga menghasilkan asam lemak bebas (free fatty acid) dan lysolipid, yang berperan dalam biosintesis eicosanoid dan platelet activating factor (PAF). Substansi-substansi tersebut merupakan mediator inflamasi, apoptosis, dan tumorigenesis yang poten. Aktivitas biologis tersebut menjelaskan mengapa inhibitor enzim PLA2 saat ini begitu diperhatikan. Hidrolisis phospholipid di membran oleh PLA2, memerlukan ikatan antara enzim dengan membran, dimana ikatan tersebut tergantung dari interaksi elektrostatik diantaranya ${ }^{6}$.

\section{Secretory PLA2-II (sPLA2-II)}

sPLA2-II terakumulasi dicairan inflamasi. Karena enzim tersebut merupakan protein fase akut, levelnya dalam plasma akan jauh meningkat selama penyakit inflamasi seperti infeksi, septic shock, dan RA. Meski demikian, proses-proses seperti karsinogenesis dan atherosclerosis juga diikuti dengan peningkatan sPLA2-II di sirkulasi. sPLA2-II diekspresikan pada organ-organ yang mengalami inflamasi, seperti limpa, thymus, usus, liver, sum-sum tulang, paru, ginjal, dan ovarium. Selain itu, banyak sel-sel lain yang juga mensekresikan sPLA2-II seperti sel endothel, sel otot polos, platelet, sel mast, neutrofil, makrofag, dan sel hepar. Seluruh sel tersebut mungkin dapat berkontribusi pada peningkatan level sPLA2-II selama respon fase akut karena sintesis sPLA2-II pada sel-sel tersebut distimulasi oleh sitokin pro-inflamasi. Ekspresi gen sPLA2-II distimulasi oleh berbagai faktor seperti hipoksia, sitokin, dan phorbol esters, serta diregulasi oleh faktor-faktor transkripsi seperti NF- $\kappa B$, PPAR, dan C/EBP. NF- $\kappa \mathrm{B}$ merupakan komponen esensial dari pathway sitokin yang menginduksi ekspresi sPLA2-II. PPARs mengontrol regulasi gen yang terlibat dalam metabolisme lipid secara umum. Sedangkan promoter gen sPLA2-II dikontrol oleh faktor C/ EBP. Aktivasi dari faktor-faktor transkripsi tersebut berada di bawah pathway yang berbeda seperti PKC dan cAMP ${ }^{6-8}$.

Interaksi dari sPLA2-II dengan phospholipid seluler tergantung dari bagian alami phospholipid tersebut. Enzim-enzim tersebut berikatan dengan afinitas yang tinggi dengan phophatatic acid (PA) dibandingkan phophatidylethanolamine (PE), phosphatidylserine (PS), dan phosphatidylcholine (PC). Ikatan spesifik tersebut merupakan hasil interaksi non-kovalen antara backbone asam amino dari protein dengan phospholipid, interaksi yang tampaknya lebih kuat pada PA dibandingkan 


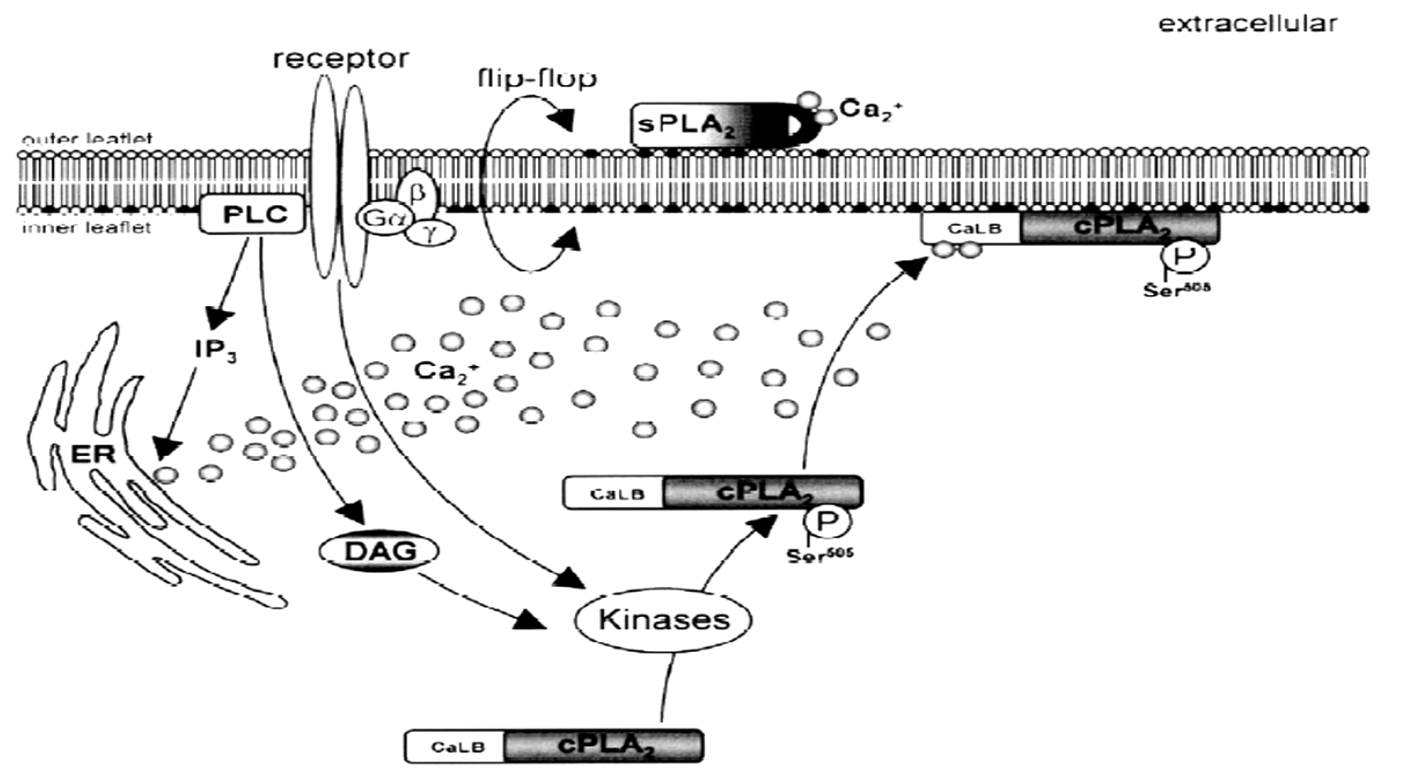

intracellular

Gambar 1. Skema mekanisme aktivasi dan lokalisasi aktivitas sPLA2-II dan cPLA2. Fosforilasi serine oleh kinase menyebabkan aktivitas katalitik dari cPLA2. $\mathrm{Ca}^{2+}$ berikatan dengan $\mathrm{N}$-terminal calcium dependent phospholipid binding domain (CaLB) dari cPLA2 dan menyebabkan translokasi ke membrane. sPLA2, juga tergantung $\mathrm{Ca}^{2+}$, yang terikat pada sPLA2-II melalui loop kalsium yang spesifik. Selain itu, sPLA2-II hanya dapat berikatan dengan membran dua arah, di mana sisi negatif membran tersebut mengikat PE dan PS. ${ }^{8}$

dengan PE, PS, dan PC. sPLA2-II dengan residu valine hanya memiliki afinitas rendah untuk PC sebagai substrat, berkebalikan dengan sPLA2-II dengan residu tryptophan yang berafinitas tinggi terhadap PC. Adanya rantai amphiphilic indole pada tryptophan memberikan penetrasi yang lebih baik untuk PLA-2 ke membran permukaan lipid. Mutan V3W dari sPLA2-II, di mana residu valine diganti dengan tryptophan menunjukkan aktivitas enzimatik yang kuat untuk $\mathrm{PC}^{4,10}$.

Perlu dicatat bahwa beberapa efek biologis dari sPLA2-II tidak tergantung dari fungsi katalitiknya, mungkin tergantung dengan interaksinya dengan reseptor spesifik. Memang, enzim tersebut menunjukkan ikatan terhadap reseptor afinitas tinggi $\left(K_{\mathrm{d}}=7.5 \mathrm{pM}\right)$ dengan berat $180 \mathrm{kDa}$, yang ada dalam otot bergaris pada kelinci. Reseptor yang disebut M-type tersebut memediasi beberapa efek fisiologis dari sPLA2-II termasuk kontraksi sel otot polos vaskuler dan proliferasi sel. Sebagai tambahan, ikatan sPLA2-II dengan reseptor tersebut akan menginduksi internalisasi sPLA2-II. Namun, sPLA2-II pada manusia tampaknya bukan merupakan ligand fisiologis untuk reseptor M-type.
Sehingga, mungkin fungsi reseptor sPLA2-II sangat berbeda antar spesies ${ }^{3,7}$.

\section{Fungsi Efektor sPLA2-II}

Dalam kondisi normal, komposisi phospholipid normal didalam dan diluar membran tidak sama. Bagian luar membran terutama terdiri atas phospholipid hidrofobik, sedangkan bagian dalam mengandung phospholipid anionic seperti PS. Karena bersifat hidrofobik, phospholipid diluar membran sel yang normal, berikatan sangat erat dan tidak terhidrolisis oleh sPLA2-II. Pada beberapa kondisi, phospholipid dibagian dalam dan luar tersebut berubah susunannya sehingga PS berada di membran luar. Proses ini disebut flip-flop. Translokasi dari phospholipid negatif tersebut (PS dan PE) dari dalam ke luar terjadi selama flip flop membran. Berkebalikan dari membran normal, bagian luar dari membran flip-flop dapat dengan mudah terhidrolisis oleh sPLA2-II. Afinitas sPLA2II terhadap membran flip-flop dikarenakan adanya 


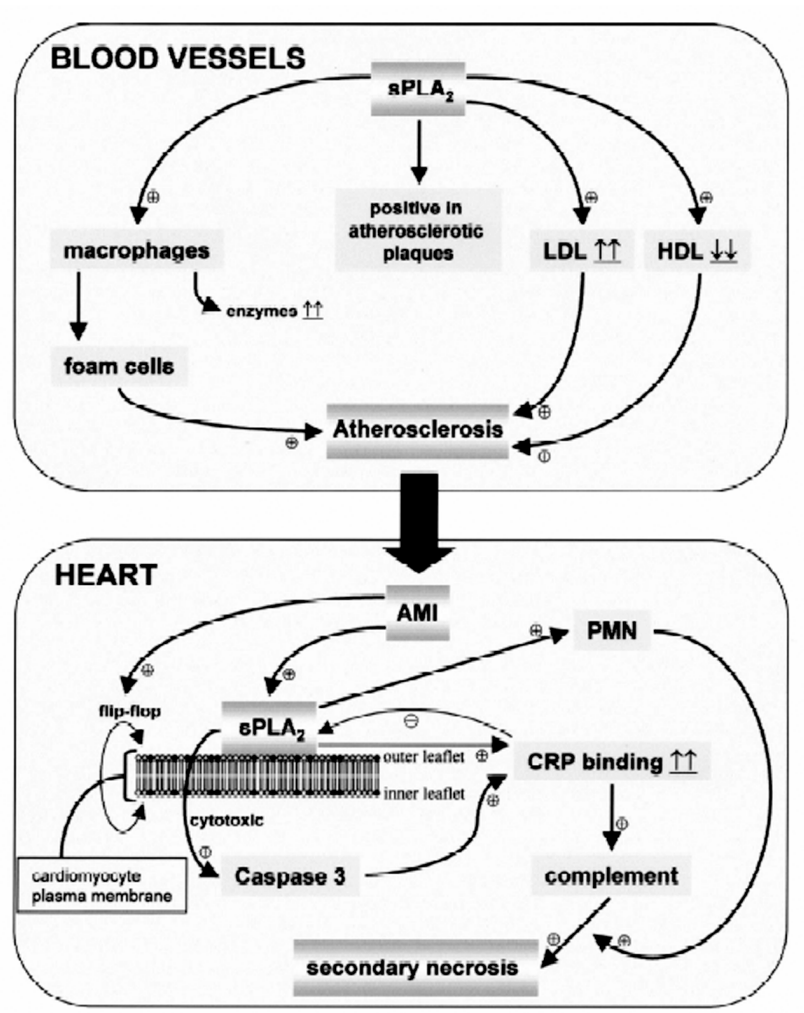

Gambar 2. Overview peran sPLA2-II pada atherosclerosis dan kerusakan cardiomyocyte post IMA. Pada pembuluh darah, sPLA2-II menginduksi atherosclerosis. sPLA2-II ditemukan pada plak atherosclerotic di mana sPLA2-II menginduksi peningkatan (small dense) LDL, penurunan HDL, dan memicu makrofag untuk mengekspresikan enzim tertentu dan membentuk foam cell. Atherosclerosis dapat memicu IMA. sPLA2-II menginduksi kerusakan cardiomyocyte selama reaksi inflamasi akibat iskemia miokard. sPLA2-II dapat berikatan dengan membran flip flop [PE dan PS] sehingga menyebabkan kematian sel melalui aktivasi caspase 3, yang menyebabkan nekrosis sekunder. sPLA2-II juga menginduksi ikatan CRP yang akan menginduksi aktivasi komplemen sehingga menimbulkan nekrosis sekunder ${ }^{8}$.

sejumlah residu kation yang membentuk lapisan pada ikatan permukaan enzim ${ }^{11-14}$.

sPLA2-II menghasilkan berbagai lysophospholipid seperti lysoPC, lysoPE, lysoPS, dan lysoPA. Menariknya, lysoPA merupakan sebuah messenger yang beraksi melalui G-protein coupled receptor, dan dapat menstimulasi agregasi platelet, proliferasi sel, dan kontraksi sel otot polos. sPLA2-II memang dapat menginduksi transduksi sinyal pada sel-sel inflamasi.
Contohnya, saat dikombinasikan dengan PAF, enzim tersebut akan menginduksi eksositosis neutrofil. Perlu dicatat bahwa fungsi biologis dari sPLA2-II pada beberapa tipe sel tidak tergantung dari fungsi katalitiknya ${ }^{5,12}$.

sPLA2-II tidak hanya menghidrolisis phospholipid pada membran sel, namun juga phospholipid dari dinding sel bakteri sehingga menyebabkan kerusakan integritas membran, sehingga sPLA2-II bersifat bakterisidal. Telah ditunjukkan juga bahwa kompleks penyerangan terhadap membran bakteri oleh komplemen akan meningkatkan permeabilitas membran, terutama gram negatif, sehingga sPLA2II dapat membuat perubahan sub-lethal pada bagian luar envelope dari bakteri. sPLA2-II juga merupakan agen bakterisidal primer untuk bakteri gram positif 5,14 .

\section{Hubungan Silang cPLA2 dengan sPLA2- II}

Pada sel mast, sPLA2-II dapat memediasi pelepasan asam arakhidonat (AA) secara selektif dengan mengikat reseptor permukaan yang diikuti induksi sinyal transduksi yang memicu aktivasi cPLA2. Hal tersebut mungkin melibatkan aktivasi jalur sinyal PKC/Raf-1/ MAPK. Selain itu, ditemukan bahwa cPLA2 dari sel fibroblast $3 Y 1$ serta lanjutan jalurnya berupa 12dan15-lipoksigenase juga dapat meningkatkan ekspresi gen sPLA2-II. cPLA2 mungkin juga mengubah permeabilitas membran untuk sPLA2-II. Contohnya, pada sel embryonal ginjal manusia, produksi AA oleh cPLA2 pada sel yang terstimulasi oleh sitokin, akan mendestabilisasi membran sel, sehingga lebih rentan terhadap hidrolisis oleh sPLA2-II. Sebaliknya, penelitian terhadap sel $S 49$ menyimpulkan bahwa CPLA2 dapat menurunkan permeabilitas membran terhadap sPLA2 selama apoptosis ${ }^{10-11}$.

cPLA2 dan sPLA2-II memiliki fungsi yang saling terkait. Contohnya, pada neutrofil yang distimulasi oleh fMLP, maka baik cPLA2 maupun sPLA2-II akan menginduksi pelepasan AA. Selain itu, dalam susunan sel keratinosit $\mathrm{HaCaT}$ manusia, inhibisi terhadap cPLA2 dan sPLA2-II akan mengeblok aktivasi NF- B oleh TNF dan mengeblok ekpresi ICAM-1. cPLA2 dan sPLA2-II mungkin teraktivasi oleh stimuli yang sama, sebagaimana tampak dalam sel NK manusia, di mana sPLA2-II dan cPLA2 teraktivasi oleh cross-linking dari CD16 6,13 . 


\section{Interaksi sPLA2-II dengan lipoprotein}

Diantara proses awal atherogenesis adalah terjadinya modifikasi partikel LDL pada dinding arteri, serta pembentukan agregat serta penyatuan droplet lipid yang relatif kecil di PC. Tingginya level small dense LDL plasma terkait dengan peningkatan resiko penyakit kardiovaskuler. Partikel small dense LDL dibentuk melalui proses reduksi phospholipid pada permukaan monolayer LDL, yang menyebabkan peningkatan interaksi dengan proteoglikan. sPLA2II mungkin membantu mengurangi kandungan phospholipid dalam LDL. Selain itu, oksidasi LDL yang diinduksi oleh 15-lipoksigenase juga meningkat karena sPLA2-II. Secara in vitro, ditunjukkan bahwa sPLA2-II membebaskan ikatan asam lemak jenuh dari phospholipid. Asam lemak tersebut meningkatkan pembentukan phospholipid bioaktif dari LDL, sehingga meningkatkan kemampuan untuk menstimulasi interaksi endothel dengan monosit. Meski demikian, native LDL merupakan substrat yang buruk untuk sPLA2-II, namun dengan sedikit oksidasi (contoh: atherosclerosis) maka kerentanan LDL terhadap hidrolisis oleh phospholipid semakin meningkat. Dalam studi lain ditunjukkan bahwa sPLA2-II diinduksi oleh sedikit modifikasi lipolytic dari LDL, sedangkan aktivitas lipolytic yang kuat ditemukan untuk sub-tipe sPLA2-X. Sehingga, mungkin perbedaan dalam komposisi, oksidasi, dan aspek lainnya, dapat mengubah kerentanan LDL terhadap sPLA2-II dan enzim PLA2 lainnya ${ }^{2,15}$.

HDL normal dapat menurunkan aktivitas sPLA2II. Meski begitu, dalam system kultur ganda dengan sel endothel manusia dan sel otot polos vaskuler, HDL gagal memberi proteksi terhadap pembentukan phospholipid aktif dari LDL oleh sPLA2-II. Selain itu, telah ditunjukkan bahwa HDL fase akut mengandung $27 \%$ serum Amyloid A (SAA), sebuah protein fase akut, yang meningkatkan aktivitas sPLA2-II. Interaksi antara HDL, SAA, dan sPLA2-II mungkin menjelaskan adanya perubahan pada metabolisme lipoprotein selama reaksi fase akut. sPLA2-II mungkin juga menghidrolisis lapisan tunggal phospholipid dari HDL. Sehingga tikus transgenic yang mengekspresikan sPLA2-II berlebih, akan memiliki kadar HDL rendah dan LDL tinggi. sPLA2-II juga menyebabkan penurunan HDL plasma sebagai respon terhadap inflamasi melalui interaksi langsung sesuai ukuran partikel dan komposisi $\mathrm{HDL}^{2,16}$.

\section{Interaksi sPLA2-II dengan sel-sel di dinding vaskuler}

Inkubasi makrofag dengan LDL dan HDL yang telah diberi sPLA2-II menyebabkan peningkatan akumulasi lipid intrasel dan memicu pembentukan foam cell. sPLA2II sendiri juga mengaktifkan makrofag melalui induksi sekresi enzim dan sitokin, sedangkan bila berinteraksi dengan LPS, sPLA2-II akan menstimulasi ekspresi iNOS dan produksi nitrit pada makrofag. Pada kultur primer dari sel endothel tikus dan pada 2 jenis sel endothel tikus yang berbeda (SVAREC dan RBE4), IL-1 $\beta$ menginduksi ekspresi gen sPLA2-II dan sekresi enzim yang tergantung dosis dan waktu. Sebaliknya, pemberian LPS pada kultur endothel primer akan menyebabkan peningkatan mRNA cPLA2, namun bukan mRNA sPLA2-II. Apakah sPLA2 berkontribusi terhadap pelepasan AA oleh sel endothel atau tidak, masih belum jelas. Setidaknya, pada sel endothel aorta burung, sebuah inhibitor sPLA2-II (CGP-43187) tidak berefek terhadap pelepasan AA yang diinduksi oleh activator non-selektif dari protein heterotrimeric guanine nucleotide-binding, yakni NaF. Selain itu, sintesis PAF yang ditingkatkan oleh VEGF pada sel HUVEC dimediasi oleh sPLA2-V dan bukan sPLA2-II ${ }^{12-15}$.

Pada sel otot polos vaskuler manusia, IL-1 tidak berefek pada level mRNA sPLA2-II, namun dapat meningkatkan mRNA cPLA2. Pada sel otot polos aorta kelinci, norepinefrin meningkatkan pelepasan AA melalui aktivasi cPLA2, namun tidak untuk sPLA2-II .

Proses utama yang diinduksi oleh sel endothel atau makrofag yang teraktivasi adalah proses koagulasi. sPLA2-II menghambat koagulasi darah secara terpisah dari kemampuannya dalam lipolysis. Enzim tersebut menghambat prothrombinase, yakni enzim yang mengkatalisis pembentukan thrombin dari prothrombin, yang terdiri dari faktor $\mathrm{Xa}$ dan $\mathrm{Va}$ yang terkumpul dipermukaan membran bila terdapat kalsium. Apakah efek antikoagulan ini relevan atau tidak pada situasi in vivo masih belum jelas. Dari studi ellipsometrik (sebuah teknik optik untuk mengukur perubahan massa yang terikat permukaan), disimpulkan bahwa konsentrasi sPLA2-II dalam plasma, pada penyakit inflamasi, tidak terlalu tinggi untuk menghambat koagulasi dengan efisien ${ }^{8,10}$.

\section{Hubungan antara SPLA2-II dan Atherosclerosis in vivo}

Pasien rheumatoid arthritis (RA) memiliki peningkat- 
an resiko kejadian kardiovaskuler. sPLA2-II pada pasien RA sangat berkorelasi dengan CRP, soluble ICAM, dan LDL-1, yang berbanding terbalik dengan HDL. Hal ini menunjukkan bahwa sPLA2-II merupakan penanda resiko kardiovaskuler. Dan memang, level sPLA2-II di sirkulasi merupakan penanda resiko independen untuk penyakit arteri koroner dan prediksi untuk kejadian kardiovaskuler. Peningkatan level sPLA2-II di sirkulasi juga dapat memprediksi kejadian koroner secara independen dari faktor resiko lain pada pasien dengan unstable angina. Peningkatan sPLA2-II di darah juga memprediksi adanya stenosis ulang pada pasien yang menjalani angioplasti koroner ${ }^{1,16}$.

Plak atherosclerosis memiliki beberapa ciri yang mirip dengan inflamasi kronis. Pada manusia, sPLA2II terdapat pada tunika intima, media, dan adventitia dari dinding atherosclerosis, dan bukan hanya pada lesi matang, tapi juga pada atherosclerosis tahap sangat awal. sPLA2-II ditemukan pada foam cell, lokasi kalsifikasi, area nekrosis sel, dan di matrix ekstra sel. Pada aorta abdominalis manusia, sPLA2-II terdapat pada semua lesi atherosclerosis tahap lanjut, namun hanya terdapat pada beberapa lesi pre-atheroma dan lesi atherosclerosis tahap awal. Sebaliknya, pada aorta thoracica, sPLA2-II ditemukan pada semua tahap lesi atherosclerosis, diketiga lapisan pembuluh darah. Pada studi arteri carotis, sPLA2-II dtiemukan pada tunika media atherosclerosis dan arteri normal. Sebaliknya, dalam studi lain, sPLA2-II tidak ditemukan pada arteri normal tanpa penebalan. Adanya sPLA2-II pada lesi atherosclerosis tidak hanya pada manusia, namun juga pada tikus. Menariknya, adanya gen Chlamydia pneumonia, HSV-1, dan CMV ditemukan terkait dengan ekspresi sPLA2-II dan tanda inflamasi lokal lain pada atherosclerosis ${ }^{17}$.

\section{sPLA2-II di Jantung}

Kami jelaskan bahwa keberadaan sPLA2-II pada infark miokard, menunjukkan bahwa enzim tersebut terlibat dalam reaksi inflamasi akibat infark jantung. sPLA2-II ini mungkin berasal dari darah ataupun diproduksi lokal dari cardiomyocyte. Penelitian Northern blotting menunjukkan adanya mRNA sPLA2-II di jantung kelinci. Sitokin seperti TNFmenstimulasi transkripsi sPLA2-II pada cardiomyocyte kelinci. Menariknya, perbatasan area infark pada manusia mengandung sel yang memiliki sPLA2-II meskipun dengan morfologi normal. Sebaliknya, cardiomyocyte normal pada sisi non-iskemik tidak berikatan dengan sPLA2-II. Sehingga ikatan sPLA2II mungkin merupakan fenomena paling awal diluar sel yang terjadi saat iskemia. Secara in vitro, kami mengidentifikasi populasi sel H9c2 dengan membran flip flop, namun tidak memiliki caspase-3, serta jalur sel cardiomyocyte. Sel-sel tersebut mati pada proses inkubasi dengan sPLA2-II. Hasil ini menyimpulkan bahwa sPLA2-II dapat menginduksi kematian sel cardiomyocyte pada infark jantung. Sebelumnya, kami mengambil hipotesis bahwa sPLA2-II juga secara tidak langsung merusak cardiomyocyte dengan meningkatkan ikatan dengan CRP, di mana ikatan tersebut akan mengaktivasi komplemen. Memang, pada infark miokard, deposit sPLA2-II terjadi lebih dulu dibanding CRP. Menariknya, ada bukti bahwa CRP dapat meregulasi aktivitas sPLA2-II sesuai konsentrasi substrat yang $\mathrm{ada}^{9,18}$.

Menurut studi diatas, disimpulkan sPLA2-II berperan dalam inflamasi pada infark miokard. Meski begitu, dari studi pada hewan coba, sPLA2-II tidak memainkan peran utama dalam perkembangan kerusakan irreversible akibat reperfusi. Perlu dicatat, pada studi ini peran sPLA2-II tidak dianalisis selama reaksi fase akut, melainkan menggunakan jantung yang diisolasi dengan perfusi Langendorf. Karena kami tidak menemukan adanya deposisi sPLA2-II hingga 6-12 jam setelah onset, maka mungkin diperlukan konsentrasi sPLA2-II sesuai reaksi fase akut untuk memediasi kerusakan inflamasi di jantung. Selain itu, darah tikus tidak mengandung banyak CRP, sehingga mungkin kerusakan akibat CRP yang diinduksi oleh sPLA2-II tidak terjadi ${ }^{4,6}$.

\section{Studi dengan inhibitor sPLA2-II}

Pada placenta, sPLA2-II specific antisense oligonucleotides A dan B dapat menghambat ekspresi dan aktivitas sPLA2-II. Inhibitor poten lain adalah LY315920 ([[3-(aminooxoacetyl)-2-ethyl-1-(phenylmethyl)-1Hindol-4-yl] oxy]acetate), sebuah agen farmakologis yang berfungsi sebagai inhibitor selektif stoikiometrik terhadap aktivitas katalitik dari sPLA2-II. LY315920 menghambat aktivitas serum sPLA2-II setelah pemberian oral atau intravena terhadap tikus transgenic. Inhibitor sPLA2-II baru lainnya yakni petrosaspongiolide $\mathrm{M}$ (diisolasi dari Caledonian marine sponge Petrosaspongia nigra), dan cacospongionolide $\mathrm{B}$ (diisolasi dari spons Fasciospongia cavernosa), memiliki efek anti inflamasi 


\section{Djanggan Sargowo: Secretory Phospholipase A2 Tipe II (SPLA II) Pada Penyakit Kardiovaskuler}

seperti pada arthritis dan edema post-inflamasi. Sayangnya, tidak ada studi dengan inhibitor-inhibitor tersebut yang dilakukan pada model infark miokard. Sehingga, masih harus diteliti apakah inhibitor sPLA2-II berguna untuk terapi IMA ${ }^{18}$.

Beberapa obat yang dikembangkan karena memiliki efek biologis lainnya, tampaknya juga menghambat aktivitas sPLA2-II atau fenomena yang diinduksi oleh sPLA2-II. Alminoprofen, sebuah NSAID (keluarga asam fenilpropionat), dan aspirin, dapat menghambat aktivitas sPLA2-II, sebagaimana heparin. NSAID lain, indomethacin, menghambat agregasi platelet akibat sPLA2-II. Tetrasiklin yang termodifikasi secara kimia, tidak hanya menghambat sPLA2-II namun juga beberapa matrix metalloproteinase yang berperan penting dalam proses atherosclerosis. Selain itu, pada pasien dengan hiperkolesterolemia, baik simvastatin maupun atorvastatin, dapat menurunkan sPLA2II. Apakah efek menguntungkan tersebut karena efek terhadap sPLA2-II atau bukan, masih harus didiskusikan lebih lanjut ${ }^{10,13}$.

\section{Diskusi}

Inflamasi berperan penting dalam atherosclerosis dan IMA, meskipun melalui mekanisme yang berbeda. Inflamasi pada atherosclerosis berkontribusi dalam rekrutmen sel inflamasi pada lesi dan pembentukan foam cell, serta pembentukan unstable plaque atau ruptur plak, yang merupakan proses utama kejadian kardiovaskuler. Pada IMA, reaksi inflamasi lokal dari miokard yang mengalami iskemia akan menyebabkan kerusakan miokard dan meningkatkan ukuran infark serta berperan dalam remodeling jaringan ${ }^{1,16}$.

Berbagai mediator inflamasi telah diketahui berperan dalam atherosclerosis dan IMA, termasuk sitokin, molekul adhesi, komplemen, dan protein fase akut. Di antara protein tersebut adalah sPLA2-II. Semua bukti terbaru menunjukkan peran sPLA2-II dalam patologi kardiovaskuler. Pada atherosclerosis, sPLA2-II tidak hanya berperan dalam aktivasi makrofag dan pembentukan foam cell, namun juga menghidrolisis LDL dan HDL sehingga meningkatkan jumlah partikel small LDL yang pro-atherogenik, dan merusak fungsi anti-atherogenik HDL. Meski deposisi sPLA2-II telah ditemukan secara lokal pada lesi atherosclerotic, dan studi klinis menunjukkan korelasi antara sPLA2-II dan komplikasi vaskuler, namun hingga saat ini peran sPLA2-II dalam menginduksi komplikasi lokal pada plak atehrosclerotik masih belum bisa diklarifikasi. Juga, relevansi dari fungsi antikoagulan dari sPLA2-II masih harus diteliti lagi. Seseorang mungkin akan berspekulasi bahwa enzim ini menginduksi pemanjangan waktu perdarahan pada plak atherosclerotic sehingga menyebabkan komplikasi vaskuler. Juga, efek bakterisidal dari sPLA2-II dalam lesi masih belum ditetapkan ${ }^{19}$.

Telah ditemukan bahwa terdapat inhibisi aktivitas sPLA2-II pada pasien dengan hiperkolesterolemia yang menerima terapi statin. Aspirin juga dapat menurunkan level sPLA2-II. Namun, hanya dapat dispekulasikan bahwa efek menguntungkan dari kedua obat tersebut merupakan efek terhadap sPLA2-II di sirkulasi ${ }^{20}$.

Kecuali bersifat antikoagulan, bukti-bukti menyatakan bahwa sPLA2-II memiliki peran yang buruk dalam lesi atherosclerotic. Meskipun peran sPLA2-II pada atherosclerotic masih bersifat spekulatif, studi dengan inhibitor sPLA2-II spesifik pada hewan dengan atherosclerosis menunjukkan hasil bagus. Juga, pada IMA, sPLA2-II tampaknya bersifat buruk sehingga menginduksi inflamasi. Sehingga, pada IMA, inhibitor spesifik untuk sPLA2-II dapat menjadi pilihan terapi. Selang waktu antara pemberian terapi sPLA2-II inhibitor pada pasien mungkin sekitar 6-24 jam setelah inset, saat darah mulai meningkat ke area infark, yang disertai dengan deposisi enzim sPLA2-II di miokardium. Berdasarkan pengetahuan kami, ikatan sPLA2-II terhadap cardiomyocyte yang mengalami infark merupakan beberapa peristiwa yang terjadi di tahap awal sehingga menyebabkan kematian sel. Kami menspekulasikan bahwa kejadian utama adalah ikatan dengan CRP, yang difasilitasi oleh sPLA2-II pada phospholipid membran di bagian luar sel yang infark. Komplemen dan neutrophil juga merupakan mediator inflamasi yang diinduksi oleh sPLA2-II dan CRP pada iskemia miokard. Sejauh apa kontribusi sPLA2-II lokal di miokard terhadap inflamasi di jantung masih belum jelas, meskipun peningkatan sPLA2-II di plasma dan deposisi di jantung seiring waktu menunjukkan bahwa sebagian besar enzim berasal dari darah. Meski begitu, pengertian saat ini mengenai peran sPLA2-II pada pasien dengan IMA mendukung penggunaan inhibitor sPLA2-II spesifik pada pasien ${ }^{1,18}$.

\section{Kesimpulan}

Sebagai kesimpulan, sPLA2-II memainkan peran patofisiologis penting pada atherosclerosis dan IMA 
(Gambar 2). Meskipun efek lokal dari sPLA2-II pada atherosclerosis masih harus diteliti lagi, namun hasil diskusi di atas menunjukkan bahwa sangat mungkin untuk mulai dilakukan penelitian in vivo pada model hewan dengan menggunakan inhibitor sPLA2-II terhadap perkembangan atherosclerosis dan terapi IMA, dan pada akhirnya studi pada manusia.

\section{Daftar Pustaka}

1. Liu PY, Li YH, Tsai WC, Chao TH, Tsai LM, Wu HL, Chen $\mathrm{JH}$. Prognostic value and the changes of plasma levels of secretory type II phospholipase A2 in patients with coronary artery disease undergoing percutaneous coronary intervention. Eur Heart J. 2003;24:1824-1832.

2. Dzavik V, Lavi S, Thorpe K, Yip PM, Plante S, Ing D, Overgaard CB, Osten MD, Lan J, Robbins K, Miner SE, Horlick EM, Cantor WJ. The sPLA Inhibition to Decrease Enzyme Release After Percutaneous Coronary Intervention (SPIDER-PCI) trial. Circulation. 2010;122:2411-2418.

3. Nijmeijer R, Willemsen M, Meijer CJ, Visser CA, Verheijen RH, Gottlieb RA, Hack CE, Niessen HW. Type II secretory phospholipase A2 binds to ischemic flip-flopped cardiomyocytes and subsequently induces cell death. Am J Physiol Heart Circ Physiol. 2003;285:H2218-H2224.

4. Van Dijk A, Krijnen PA, Vermond RA, Pronk A, Spreeuwenberg M, Visser FC, Berney R, Paulus WJ, Hack CE, Van Milligen FJ, Niessen HW. Inhibition of type 2A secretory phospholipase A2 reduces death of cardiomyocytes in acute myocardial infarction. Apoptosis. 2009;14:753-763.

5. Nijmeijer R, Lagrand WK, Baidoshvili A, Lubbers YT, Hermens WT, Meijer CJ, Visser CA, Hack CE, Niessen HW. Secretory type II phospholipase A(2) binds to ischemic myocardium during myocardial infarction in humans. Cardiovasc Res. 2002;53:138-146.

6. Nijmeijer R, Lagrand WK, Baidoshvili A, Lubbers YT, Hermens WT, Meijer CJ, Visser CA, Hack CE, and Niessen HWM.Secretory type II phospholipase A(2) binds to ischemic myocardium during myocardial infarction in humans. Cardiovasc Res53: 138-146, 2002.

7. Rosensol, RS and Camejo, EH. Phospholipase $A_{2}$ enzymes and the risk of atherosclerosis. Eur Heart J (2012) 33 (23): 2899-2909.

8. Niessen HWM, Krijnen PAJ, Viseer CA, Meijer CJLM, Hack, CE. Type II secretory phospholipase A2 in cardiovascular disease: a mediator in atherosclerosis and ischemic damage to cardiomyocytes?. Cardiovasc Res (2003) 60 (1): 68-77.
9. Jönsson-Rylander AC, Lundin S, Rosengren B, Pettersson C, Hurt-Camejo E. Role of secretory phospholipases in atherogenesis. Curr Atheroscler Rep 2008;10:252-259.

10. Singer AG, Ghomashchi F, Le Calvez C, Bollinger J, Bezzine S, Roualt M, Sadilek M, Nguyen E, Lazdunski M, Lambeau $\mathrm{G}$, Gelb MH. Interfacial kinetic and binding properties of the complete set of human and mouse groups I, II, V, X, and XII secreted phospholipases $A_{2}$. J Biol Chem 2002;277:4853548549.

11. Rodriguéz-Lee M, Bondjers G, Camejo G. Fatty acid-induced atherogenic changes in extracellular matrix proteoglycans. Curr Opin Lipidol 2007;18:546-553.

12. Hurt-Camejo E, Camejo G, Sartipy P. Phospholipase $A_{2}$ and small, dense low-density lipoprotein. Curr Opin Lipidol 2000;11:465-471.

13. Hurt-Camejo E, Camejo G, Peilot H, Oörni K, Kovanen P. Phospholipase $\mathrm{A}_{2}$ in vascular disease. Circ Res 2001;89:298304.

14. Kimura-Matsumoto M, Ishikawa Y, Komiyama K, Tsuruta T, Murakami M, Masuda S, Akasaka Y, Ito K, Ishiguro S, Morita H, Sato $\mathrm{S}$, Ishii T. Expression of secretory phospholipase $\mathrm{A}_{2} \mathrm{~s}$ in human atherosclerosis development. Atherosclerosis 2008;196:8191.

15. Hanasaki K, Yamada K, Yamamoto S, Ishimoto Y, Saiga A, Ono T, Ikeda M, Notoya M, Kamitani S, Arita H. Potent modification of low density lipoprotein by group $\mathrm{X}$ secretory phospholipase $A_{2}$ is linked to macrophage foam cell formation. J Biol Chem 2002;277:29116-29224.

16. Koenig W, Vossen CY, Mallat Z, Brenner H, Benessiano J, Rothenbacher D. Association between type II secretory phospholipase $A_{2}$ plasma concentrations and activity and cardiovascular events in patients with coronary heart disease. Eur Heart J 2009;30:2742-2748.

17. Kugiyama K, Ota Y, Sugiyama S, Kawano H, Doi H, Soejima H, Miyamoto S, Ogawa H, Takazoe K, Yasue H. Prognostic value of plasma levels of secretory type II phospholipase $\mathrm{A}_{2}$ in patients with unstable angina pectoris. Am J Cardiol 2000;86:718722.

18. Mouchlis VD, Barbayianni E, Mavromoustakos TM, Kokotos G. The application of rational design on phospholipase $A_{2}$ inhibitors. Curr Med Chem 2011;18:2566-2582.

19. Zheng G-H, Chen H-Y, Xiong S-Q, Chu J-F. Lipoproteinassociated phospholipase $\mathrm{A}_{2}$ gene $\mathrm{V} 279 \mathrm{~F}$ polymorphisms and coronary heart disease: a meta-analysis. Mol Biol Rep 2011;38:4089-4099.

20. Rosenson RS. Lp-PLA2 and risk of atherosclerotic vascular disease. Lancet 2010;375:1498-1500. 